$\begin{array}{r}\text { Phinisi Integration Review } \\ \text { Vol. 1, No.2, Agustus 2018 Hal 242-258 } \\ \text { Website: } \text { http://ojs.unm.ac.id/pir } \\ \hline\end{array}$

\title{
Peristiwa Galung Lombok 1946-1947
}

\author{
Herlina \\ Pendidikan IPS Kekhususan Pendidikan Sejarah \\ Program Pascasarjana Universitas Negeri Makassar \\ Email: herlina@gmail.com
}

\begin{abstract}
Abstrak. Penelitian bertujuan untuk: mendeskripsikan latar belakang terjadinya peristiwa sejarah yangterjadi pada tahun 1946-1947 di Galung Lombok Polewali Mandar Sulawesi Barat yakni pembantaian yang dilakukan oleh pasukan Westerling di bawah Kepemimpinan Vermeulen yang mengakibatkan jatuhnya korban yang terdiri para Pejuang dan rakyat sipil, dan untuk merekonstruksi peristiwa Galung Lombok di Kecamatan Tinambung Kabupaten Polewali Mandar dan mengetahui dampak peristiwa Galung Lombok dalam upaya menegakkan dan mempertahankan Kemerdekaan Republik Indonesia di Sulawesi Selatan. Jenis penelitian adalah deskriptif kualitatif yang bersifat analisis dengan menggunakan metode historis.Tehnik pengumpulan data yang digunakan yaitu pengumpulan dokumen, observasi, wawancara, dan dokumentasi. hasil penelitian menunjukkan bahwa Peristiwa Galung Lombok merupakan peristiwa pembantaian orang Mandar yang terjadi pada 1 februari 1947 ini dapat di lihat dari tiga fase, dimana Fase pertama Pelaksanaan eksekusi mati terhadap 32 orang pejuang Mandar yang ditahan di penjara KNIL Majene. Fase kedua;menembak mati orang - orang yang di curigai sebagai Ekstremis, dan Fase keTiga; Tragedi pembersihan itu sendiri. Hasil penelitian menunjukkan bahwa Peristiwa Galung Lombok merupakan tragedi pembantaian orang Mandar yang dilatarbelakangi oleh adanya keinginan pemerintah Belanda untuk menanamkan kembali kekuasaannya di Indonesia khususnya di daerah Mandar. Karena keinginan pemerintahan Belanda yang ada di Sulawesi Selatan di tolak keras oleh para pejuang di berbagai daerah dan mengakibatkan perlawanan dari kelasyakaran kelasyakaran terhadap pemerintah Belanda di Sulawesi, hal tersebutlah yang melatarbelakangi sehingga dikeluarkan surat keputusan keadaan darurat perang (Staat Van Oorlog en Beleg) yang berlaku bagi Afdeling Makassar, Bonthain, Pare-pare dan Afdeling Mandar dan menurunkan Westerling dan pasukan Khusus atau Datasemen Special Topen(DST). Peristiwa ini telah menimbulkan berbagai dampak bagi masyarakat khususnya keluarga korban.
\end{abstract}

Kata Kunci : Peristiwa Galung Lombok.

Abstract. This study aims to describe the background of the occurrence of historical events that occurred in 1946-1947 at Galung Lombok Polewali Mandar, West Sulawesi, namely the massacre carried out by Westerling's forces under Vermeulen Leadership which resulted in casualties consisting of fighters and civilians and this research aims to reconstruct the Galung Lombok incident in the Tinambung District of Polewali Mandar District and find out the impact of the Galung Lombok incident in an effort to uphold and maintain the Independence of the Republic of Indonesia in South Sulawesi. This type of research is a qualitative descriptive analysis using historical methods. Data collection techniques used are document collection, observation, interviews, and documentation. the results showed that the Galung Lombok incident was a Mandar massacre which took place on February 1, 1947 and could be seen from three phases, in which the first phase of the execution was the execution of 32 Mandar fighters detained in the Majene KNIL prison. Second phase: shooting dead people suspected of being extremists, and third phase; The 
cleansing tragedy itself. The results showed that the Galung Lombok incident was a tragedy of the Mandar massacre which was motivated by the Dutch government's desire to reinvest its power in Indonesia, especially in the Mandar region. Because the wishes of the Dutch government in South Sulawesi were strongly rejected by the fighters in various regions and resulted in resistance from firefighting fire against the Dutch government in Sulawesi, it was the background that issued a decree of martial law (Staat Van Oorlog en Beleg) in force. for Afdeling Makassar, Bonthain, Pare-pare and Afdeling Mandar and bring down Westerling and Special Forces or Special Topen Datasemen (DST). This event has caused various impacts on the community, especially the families of the victims.

Keywords: Event Galung Lombok.

Ini adalah artikel dengan akses terbuka dibawah licenci CC BY-NC-4.0 (https://creativecommons.org/licenses/by-nc/4.0/ )

\section{PENDAHULUAN}

Keadaan Darurat Perang (Staat Van Oorlog en beleg) yang berlaku bagi Afdeling Mandar, Pare -Pare, Makassar dan Bonthain pada tanggal 11 Desrmber 1946, pada dasarnya merupakan pilihan untuk dapat memulihkan kedudukan pemerintah Belanda di Sulawesi Selatan yang sudah tidak berdaya. Kemerosotan kedudukan kekuasaan pemerintah sipil Belanda itu disebabkan semakin meningkatnya perlawanan para pejuang kemerdekaan yang menentang usaha Belanda untuk menghidupkan kembali pemerintahan kolonialnya di Indonesia (Poelinggomang, 2002:1).

Berawal dari pernyataan kemerdekaan Indonesia pada tanggal 17 Agustus 1945 yang sesungguhnya bukan hanya merupakan pusat peristiwa dari sejarah Indonesia, tetapi juga merupakan suatu elemen yang sangat kuat dalam pandangan tentang negara Indonesia, Sebagaimana bunyi dari Pembukaan UndangUndang Dasar (UUD)1945 yang pertama yaitu "bahwa sesungguhnya kemerdekaan itu ialah hak segala bangsa dan oleh sebab itu, maka penjajahan di atas dunia harus dihapuskan, karena tidak sesuai dengan peri kemanusiaan dan peri keadilan"(UUD 1945 Ayat 1).

Perjuangan kemerdekaan Indonesia sebagai tonggak sejarah mempertahankan Kemerdekaan Republik Indonesia yang diproklamasikan pada tanggal 17 Agustus 1945 memiliki pesan, arti dan nilai perjuangan yang tinggi. Bahkan tidak jarang diperdengarkan suatu pernyataan tentang "pewarisan dan penghayatan nilai - nilai ' 45 " hal ini didasarkan atas kenyataan bahwa proklamasi kemerdekaan itu bukan hanya merupakan pusat peristiwa dari sejarah Indonesia, tetapi juga merupakan suatu elemen yang kuat dari pandangan tentang Indonesia.

Harus diakui bahwa pasca kemerdekaan, negara Indonesia memasuki masa yang dipenuhi oleh sebuah harapan dimana akan hidup berbangsa yang lebih baik. Harapan hidup sebagai bangsa yang merdeka dan berdaulat telah dijadikan sebagai prinsip hidup rakyat Indonesia yang mana dalam hal ini bukan bentuk Slogan saja. Mewujudkan dan mempertahankan kemerdekaan merupakan idealisme tertinggi bagi seluruh rakyat Indonesia dalam konteks penjajahan atau kolonialisme. Sikap inilah yang pada dasarnya menjiwai berbagai jenis aktivitas pergerakan rakyat Indonesia pasca proklamasi. Aktivitas pergerakan ini secara menyeluruh dilakukan oleh rakyat Indonesia di daerah masing-masing. Dengan adanya berita kemerdekaan ini maka pemuda dan rakyat umumnya menyambut dengan perasaan haru dan lega. Dimana-mana terdengar pekikan "merdeka" mengumandang serta menjadi salam setiap pertemuan. Lambang merah putih mulai nampak baik yang terpasang di dada baju, peci, atau songkok para pemuda maupun pada setiap rumah- rumah penduduk, yang menandakan bahwa mereka golongan merah putih dan mendukung kemerdekaan. (Naim, 2013:53).

Makna yang terkandung dalam proklamasi yang berisi suatu pernyataan kemerdekaan memberitahukan kepada seluruh bangsa Indonesia bahwa pada saat itu Indonesia 
telah lepas dari penjajahan, akan tetapi orang Jepang melarang berita Proklamasi untuk diumumkan, sehingga berita proklamasi itu tidak pernah diketahui secara resmi di Sulawesi. Berita kemerdekaan baru didengar setelah pesawat radio milik Jepang dapat dipergunakan dengan leluasa dan sejak saat itu rakyat mengetahui bahwa Dr.Ratulangi telah menjadi gubernur di Sulawesidan pengangkatan itu diterima oleh seluruh rakyat Sulawesi dengan gembira(Kadir dkk, 1984:145)

Hal yang sama terjadi di Afdeling Mandar Jepanpun membatasi penyebaran berita proklamasi sehingga berita kemerdekaan tersebut kurang diyakinkan. Berita proklamasi di wilayah Afdeling Mandar diketahui dua hari setelah Soekarno-Hatta membacakan proklamasi kemerdekaan yaitu pada tanggal 19 Agustus 1945 yang disampaikan oleh Kapten Miyasto Taitjo (Kapten Angkatan Darat Jepang untuk daerah Afdeling Mandar) kepada Ibu Depu dan Riri Amin Daud.Dengan cepat berita proklamasi itu tersebar di seluruh daerah-daerah kawasan Mandar, khususnya didaerah Balanipa baik penyampaian langsung oleh Mara'dia Ibu Depu, Ririn Amin daud serta tokoh tokoh pergerakan pemuda lainnya. Kemudian berita tersebut disebarkan ke seluruh pelosok daerah Afdeling Mandar dan pengibaran bendera Merah putih dilakukan di berbagai daerah begitupun Di Majene, berita Proklamasi diterima oleh Andi Tonra yang disampaikan tokoh-tokoh pergerakan dan rakyat yang diutus oleh Ibu Depu(Asdi, 2007:26)

Pengibaran bendera merah putih setelah diproklamirkan kemerdekaan Republik Indonesia di daerah Balanipa khususnya di Mandar pada umumnya adalah H.A Depu dan beberapa tokoh pejuang di Mandar yang bertempat di distrik Tapango wilayah Matakali. Dalam upacara tersebut yang bertindak sebagai komandan upacara adalah KH. Arif Liwa, dan dihadiri oleh H.A Depu didampingi oleh Mara'dia Tapango H.Muh Daraza serta dihadiri oleh sejumlah tokoh pejuang dari Kelasykaran Kris Muda Mandar ( Kebangkitan Rahasia Islam Muda Mandar) dimana peristiwa tersebut dikenal dengan "batu bandera" Hal ini pertanda semangat dalam meraih kemerdekaan dan mengusir penjajahan yang ingin meletakkan kekuasaanya kembali di tanah Mandar. Hal serupa juga terjadi di beberapa daerah, dimana pengibaran bendera merah putih dilakukan di berbagai daerah di Afdeling Mandar seperti: Campalagian, dan Tinambung dalam menyambut kemerdekaan Republik Indonesia (Asdi, 2000: 168).

Di Sulawesi Selatan misalnya, pasca proklamasi pihak-pihak tertentu baik personal maupun kelompok melakukan koordinasi untuk menyambut sekaligus merealisasikan fungsi dan makna dari sebuah kemerdekaan. Oleh kerena itu didaerah ini dapat dilihat berbagai jenis aktivitas pergerakan dalam mempertahankan kemerdekaan Indonesia. Meskipun kemerdekaan Indonesia adalah sebuah revolusi karna terjadi secara cepat dan mendasar, namun Belanda tidak begitu saja menerima kedaulatan dan kemerdekaanIndonesia. Dalam suasana proklamasi, sementara itu dilain pihak unsur kolonial melancarkan issu dan propaganda bahwa kemenangan Sekutu terhadap pendudukan militer Jepang adalah juga kemenangan Belanda yang kelak pasti akan kembali memerintah. Belanda yang merasa memiliki hak atas wilayah bekas jajahan Jepang, mengambil inisiatif untuk membicarakan pengambilalihan wilayah teritorial Indonesia agar tetap menjadi hak Belanda (Junaeda, 2013:3)

\section{Berdasarkan Civil Affair Agreement} pada akhir september 1945 NICA mulai melaksanakan tugas untuk menegakkan kembali pemerintahan sipil Hindia Belanda. Ia bertindak secara sepihak dan menyatakan tidak berlaku lagi uang Jepang dan sebagai penggantinya di keluarkan uang NICA. Mempersenjatai orangorang Belanda, Indo, Orang-orang Ambon dimana mereka mendemonstrasikan arak arakan mobil sambil menyanyikan lagu lagu rakyat belandadan banyak lagi tindakan-tindakan yang dilakukan yang memancing amarah rakyat. Didaerah Mandarpun pada awal bulan Oktober 1945, menjelang masuknya tentara NICA dimana kapal berbendera Belanda yang sedang berlabuh dipelabuhan Majene dengan niat kedatangan kapal itu bermaksud untuk menyelidiki reaksi rakyat bila kelak NICA datang memasuki daerah Mandar, Akan tetapi para pemuda yang menyaksikan kedatangan kapal tersebut secara spontanitas melakukan aksi protes hingga akhirnya kapal Belanda tersebut meninggalkan pelabuhan (Naim, 2013).

Pada awalnya kedatangan Sekutu yang mengikutsertakan NICA disambut oleh masyarkat dan pejuang, tetapi tindakan-tindakan Sekutu lama-kelamaan merendahkan martabat bangsa Indonesia yang sudah merdeka. Ditambah lagi Sekutu mempersenjatai tentara 
KNIL. Ketegangan-ketegangan mulai muncul pada tanggal 13 Januari 1946, yaitu ketika ketika tentara KNILmulai mengadakan aksi-aksi pertamanya di kota Majene. Dalam aksi tersebut bendera Belanda dikibarkan di dalam tangsi kota Majene, dan semua bendera marah putih yang berkibar, baik yang ada di rumah penduduk maupun di kantor kantor diturunkan, selain itu di toko-toko dan pasar mereka melakukan tindakan semena-mena. Insiden tersebut menimbulkan rasa curiga bagi masyarakatbahwa keberadaan pasukan Sekutu tersebut menyertakan aparatNICAuntuk menanamkan kembali kekuasaan di Indonesia(Amir, 2014:114)

Aksi penurunan bendera tersebut tidak hanya di Majene saja, tetapi juga dilanjutkan ke daerah-daerah lainnya dalam wilayah Afdeling Mandar. Mulai saat itu, bendera Merah Putih yang berkibar di mana-mana harus turun secara paksa dan digantikan bendera Belanda yang berarti bahwa daerah tersebut sudah menjadi daerah pendudukan NICA. Tindakan yang dilakukan tentara Sekutu yang diboncengi tentara NICA lama-kelamaan melakukan aksi sewenang-wenang dan melakukan tindakan kekerasan kepada masyarakat.Peristiwa yang dituturkan diatas telah membuktikan bahwa kedatangan sekutu dengan membonceng tentara NICA benar-benar merupakan suatu usaha yang nyata untuk mengembalikan kekuasaan Hindia Belanda di daerah Mandar(Amir, 2010:154).

Ambisi yang dilakukan oleh pemerintahan Belanda mungundang gejolak perlawanan dari beberapa kelompok perjuangan rakyat baik Sulawesi maupun daerah lain. Pemerintah Belanda tidak berfikir panjang, satu satunya jalan untuk melakukan pengikisan terhadap para pejuang rakyat di Sulawesi adalah menerjungkan Kapten Raymond Westerling kemedan pertempuran. Hingga tercapainya pembentukan Negara federasi. Salah satu perlawanan yang paling sengit terhadap Belanda diluar Pulau Jawa adalah Daerah Sulawesi Selatan. Daerah yang terletak di tengah tengah kepulauan Indonesia dengan ibukota Makassar tidak hanya menjadi salah satu pusat perlawanan menentang kehadiran dan usahaNICA yang hendak menegakkan kembali kekuasaan dan pemerintahan Hindia Belanda, tetapi menjadi salah satu pusat perjuangan dalam membela dan mempertahankan kemerdekaan Indonesia. Hal itu dimungkinkan karena terbentuknya berbagai organisasi perjuangan, terutama organisasi kelasykaran (Kadir dkk, 1984:156).
Harvey Dalam Kadir menjelaskan bahwa "pembentukan organisasi perjuangan tersebut tidak terlepas dari dukungan rakyat dan para Bangsawan yang senantiasa mendorong para pemuda pejuang untuk mempertahankan Proklamasi Kemerdekaan Republik Indonesia".Khususnya para pemuda yang melakukan aksi protes dengan memasang tulisan "R.I."di berbagai gedung sebagai tanda bahwa gedung-gedung tersebut adalah hak milik Republik Indonesia. Pada dasarnya perjuangan dalam mempertahankan kemerdekaan Republik Indonesia dilakukan melalui jalur diplomasi dengan jalur damai tanpa menggunakan senjata hal ini di dukung oleh beberapa organisasi organisasi kelaskaran rakyat.

Dalam pidato Ratulangi mengatakan bahwa tujuan bersama adalah kemenangan , olehnya itu jangan ada bertindak sendiri-sendiri ,sebab korban yang jatuh akibat bertindak sendiri-sendiri merupakan korban yang sia sia. Pada dasarnya pidato Ratulangi menjelaskan bahwa arah perjuangan yang digagas secara bersama-sama itu adalah semata-mata untuk mencapai kemenangan. Oleh karena itu, perjuangan harus dilakukan secara bersamasama dan menghindari bentuk perjuangan yang dilakukan secara sepihak. Maksud dari ucapan Ratulangi itu pada dasarnya ingin menegaskan bahwa perjuangan yang dilakukan itu harus satu komando, dan komando itu ada pada kendali Ratulangi sebagai Gubernur Sulawesi" (Harvey dalam Kadir 1984:155).

Menurut Abdullah dalam Thalib Banru menerangkan bahwa peristiwa Galung Lombok pada 1 Februari 1947 yang diawali dengan menggiring para tawanan ekstremis dari penjara Majene ke Galung Lombok yang akan dieksekusi. Eksekusi ini disaksikan oleh masyarakat yang sengaja dikumpulkan untuk menyaksikan eksekusi.Hal ini dilakukan sebagai ancaman untuk rakyat yang melakukan perlawanan terhadap Belanda, akan tetapi kebuasan pasukan Westerling tidak hanya berakhir sampai disitu, akan tetapi setelah pasukan Westerling mendengar berita tewasnya pasukan patroli Belanda menjadi puncak kemarahan pasukan Westerling hingga akhirnya dengan secara membabi buta, menembaki kerumunan warga dengan rentetan tembakan senapan. Pembantaian manusia secara massive, keji dan biadab telah terjadi hanya dalam beberapa waktu saja. (Thalib Banru,2017:20). 


\section{TINJAUAN PUSTAKA}

\section{A.Deskripsi Teoritister}

Penelitian sejarah berkaitan dengan peristiwa Galung Lombok 1946-1947 pada dasarnya membahas tentang eksistensi pergerakan rakyat Indonesia dalam mempertahankan kemerdekaan.

Penulis menyadari bahwa sejarah sebagai ilmu pengetahuan membutuhkan ilmu lain untuk analisis demi memperoleh infomasi yang objektif pada penelitian ini.Sebagai upaya untuk menjelaskan tentang peristiwa di Mandar tersebut tentunya tidak lepas dari kekuasaan, nasionalisme, kebangsaan, kritik dan konflik yang pastinya akan ada perubahan sosial akibat dari kebijakan yang dijalankanPemerintah Belanda. Oleh karena itu, penulis memetakan tentang konsep dan teori yang berkaitan dengan penelitian mengenai peristiwa Galung Lombok yaitu: konsep kekuasaan, nasionalisme, kebangsaan,teori kritik, teori konflik dan Teori perubahan sosial. Adapun konsep dan teori tersebut sebagai berikut:

\section{Konsep Nasionalisme}

Pengertian nasionalisme berasal dari kata nation (bangsa). Nasionalisme adalah suatu paham atau ajaran untuk mencintai bangsa dan negara atas kesadaran keanggotaan/warga negara yang secara potensial bersama-sama mencapai, mempertahankan, dan mengabdikan identitas, integritas, kemakmuran dan kekuatan bangsanya. Nasionalisme merupakan suatu paham yang mengutamakan persatuan dan kebebasan bangsa. Nasionalisme memuat beberapa prinsip yaitu: kesatuan, kebebasan, kesamaan, kepribadian, dan prestasi. Nasionalisme juga dapat diartikan sebagai perpaduan dari rasa kebangsaan dan paham kebangsaan. Dengan semangat kebangsaan yang tinggi, kekhawatiran akan terjadinya ancaman terhadap keutuhan bangsa akan dapat terhindarkan. Nasionalisme merupakan sebuah penemuan sosial yang paling menakjubkan dalam perjalanan sejarah manusia, paling tidak seratus tahun terakhir. Tidak ada satu pun ruang sosial di muka bumi yang lepas dari pengaruh ideologi ini. Tanpa nasionalisme, lajur sejarah manusia akan berbeda sama sekali. Berakhirnya perang dingin dan semakin merebaknya gagasan dan budaya globalisme (internasionalisme) pada dekade 1990-an hingga sekarang, khususnya dengan adanya teknologi komunikasi dan informasi yang berkembang dengan sangat pesat. Nasionalisme yang melahirkan bangsa berada di titik persinggungan antara politik, teknologi dan transformasi sosial (Kohn, 1984:11)

Menurut John Hutchinson (2000:34) nasionalisme lebih merupakan sebuah fenomena budaya daripada fenomena politik karena dia berakar pada etnisitas dan budaya promodern. Kalaupun nasionalisme bertransformasi menjadi sebuah gerakan politik, hal tersebut bersifat superfisial karena gerakan-gerakan politik nasionailisme pada akhirnya dilandasi oleh motivasi budaya, khususnya saat terjadi krisis identitas kebudayaan. Pada sudut pandang ini, gerakan politik nasionalisme adalah sarana mendapatkan kembali harga diri etnik sebagai modal dasar membangun sebuah negara berdasarkan kesamaan budaya. Semangat kebangsaan akan mengalir rasa kesetiakawanan sosial, semangat rela berkorban dan dapat menumbuhkan jiwa patriotisme. Rasa kesetiakawanan sosial akan mempertebal semangat kebangsaan suatu bangsa. Semangat rela adalah kesediaan untuk berkorban demi kepentingan yang besar atau demi negara dan bangsa telah mengantarkan bangsa Indonesia untuk merdeka. Bagi bangsa yang ingin maju dan mencapai tujuannya, selain memiliki semangat rela berkorban, juga harus didukung dengan jiwa patriotik yang tinggi.

Makna nasionalisme : 1) Suatu paham yang berpendapat bahwa kesetiaan tertinggi harus diserahkan pada negara 2) Suatu perasaan yang mendalam akan ikatan terhadap tanah air sebagai tumpah darah 3) Suatu proses pembetukan atau pertumbuhan bangsa-bangsa 4) Suatu bahasa dan simbolisme bangsa 5) Suatu gerakan sosial dan politik demi kepentingan bangsa 6) Suatu doktrin atau ideologi bangsa, baik umum maupun khusus Menurut Kamus Besar Bahasa Indonesia dalam Listiyarti (2007:26) " nasionalisme berasal dari kata nasional dan isme yaitu paham kebangsaan yang mengandung makna kesadaran dan semangat cinta tanah air, memiliki rasa kebangsaan bangsa, atau memelihara kehormatan bangsa," (Chotib dan Djazuli 2007 :24)

"Nasionalisme adalah sikap dan semangat berkorban untuk melawan bangsa lain" . Nasionalisme memiliki beberapa bentukbentuk menurut Retno Listyarti (2007 :28) antara lain : 1) Nasionalisme kewarganegaraan (nasionalisme sipil) adalah nasionalisme dimana negara memperoleh kebenaran politik dari 
partisipasi aktif rakyatnya. Keanggotaan suatu bangsa bersifat sukarela. Bentuk nasionalisme ini mula-mula dibangun oleh Jean-Jacques Rousseau dan menjadi bahan tulisannya. 2) Nasionalisme etnis atau etnonasionalisme adalah dimana negara memperoleh kebenaran politik dari budaya asal atau etnis sebuah masyarakat. Keanggotaan suatu bangsa bersifat turuntemurun. 3) Nasionalisme romatik adalah bentuk nasionalisme etnis dimana negara memperoleh kebenaran politik sebagai suatu yang alamiah dan merupakan ekspresi dari bangsa atau ras. Nasionalisme romantik menitik beratkan pada budaya etnis yang sesuai dengan idealisme romantik 4) Nasionalisme budaya adalah nasionalisme dimana negara meperoleh kebenaran politik dari budaya bersama dan tidak bersifat turun-temurun seperti warna kulit 5) Nasionalisme kenegaraan adalah merupakan variasi nasionalisme kewarganegaraan yang sering dikombinasikan dengan nasionalisme etnis. Dalam nasionaalisme kenegaraan bangsa adalah suatu komonitas yang memberikan kontribusi terhadap pemeliharaan dan kekuatan negara. 6) Nasionalisme agama adalah nasionalisme dimana negara memperoleh legitimasi politik dari persamaan agama.

Selain itu, pada dasarnya nasionalisme yang muncul di negara-negara yang memiliki tujuan nasionalisme sebagai berikut : 1) Menjamin kemauan dan kekuatan mempertahankan masyarakat nasional melawan musuh dari luar sehingga melahirkan semangat rela berkorban. 2) Menghilangkan ekstremisme (tuntutan yang berlebihan ) dari warga negara (individu dan kelompok). Berdasarkan pendapat di atas, bahwa nasionalisme adalah suatu paham atau ajaran untuk mencintai bangsa dan negara atas kesadaran keanggotaan/warga negara yang secara bersama-sama mencapai, mempertahankan, dan mengabdikan identitas, integritas, kemakmuran dan kekuatan bangsa.Prinsip-prinsip Yang Terkandung Dalam Nasionalisme Nasionalisme dalam arti luas adalah paham kebangsaan yang meletakkan kesetian kesetiaan tertinggi individu terhadap bangsa dan tanah airnya dengan memandang bangsanya itu merupakan bagian dari bagian lain di dunia. Nasionalisme dalam arti luas mengandung prinsip-prinsip yaitu kebersamaan, persatuan dan kesatuan serta demokrasi/demokratis. 1)Prinsip kebersamaan Prinsip kebersamaan menuntut setiap warga negara untuk menempatkan kepentingan bangsa dan negara di atas kepentingan pribadi dan golongan, 2) Prinsip persatuan dan kesatuan Prinsip persatuan dan kesatuan menuntut setiap warga negara harus mampu mengesampingkan pribadi atau golongan yang dapat menimbulkan perpecahan dan anarkis (merusak), utnuk menegakkan prinsip persatuan dan kesatuan, setiap warga negara harus mampu mengedepankan sikap : kesetiakawan sosial, perduli tehadap sesama, solidarias dan berkeadilan sosial. 3) Prinsip demokrasi Prinsip demokrasi memandang : bahwa setiap warga negara mempunyai kedudukan, hak dan kewajiban yang sama, karena hakikanya kebangsaan adalah adanya tekad unuk hidup bersama mengutamakan kepentingan bangsa dan negara yang tumbuh dan berkembang dari bawah untuk bersedia hidup sebagai bangsa yang bebas, merdeka, berdaulat, adil dan makmur.

\section{Teori Strukturasi (Structuration)}

Teori ini menjelaskan tentang hubungan antara agensi dengan struktur. Dimana semua tindakan sosial melibatkan struktur dan semua struktur melibatkan tindakan sosial, dan terjalin erat dalam aktivitas atau praktik yang terus menerus di jalankan manusia. Hal ini dapat kita melihat dari pengertian antara agensi dan strukturasi dimana agensi di artikan sebagai individu yang bertanggung jawab atas peristiwa dan peristiwa tidak akan terjadi jika individu tidak intervensi, sedangkan struktur ialah hal hal yang menstrukturkan seperti aturan dan sumber daya serta sarana yang memungkinkan pengikatan ruang dan waku yang memproduksi praktik-praktik sosial dalam sistem-sistem sosial kehidupan masyarakat. Hal ini juga selaras dengan yang di kemukakan oleh Giddens yang mengatakan, "setiap riset dalam ilmu sosial atau sejarah selalu menyangkut penghubungan tindakan (seringkali di sinonimkan dengan agen) dengan struktur ... Namun, dalam hal ini tak berarti bahwa struktur 'menentukan' tindakan atau sebaliknya” (Ritzer, Goodman. 2003:507).

Keterulangan tindakan sosial itu menunjukkan bahwa ada pola tetap yang berlaku, bukan sekali saja, melainkan berulang kali dalam lintas ruang dan waktu. Berdasarkan argumen di atas, maka Giddens menekankan bahwa perkara sentral ilmu sosial adalah hubungan antara "Struktur" (trukture) dan "pelaku" (Agency). Karena gagasannya tentang hubungan antara struktur dan pelaku inilah, maka Giddens lebih dikenal dengan teori "Strukturasunya" yang banyak diartikan sebagai 
proses terbentuknya sebuah Struktur. Menurut Giddens dalam Wirawan bahwa manusia selalu mempunyai ide tentang dunia sosial, tentang dirinya sendiri, tentang masa depannya dan tentang kondisi kehidupannya. Melalui idenya itu manusia masuk kedalam dunia sambil mempunyai niat untuk mempengaruhi dan merubahnya (Wirawan,2011:292).

Menurut Wirawan dalam Teori-teori Sosial mengemukakan bahwa teori srukturasi juga tidak lepas dari konteks ruang dan waktu, dimana menurut Giddens ruang dan waktu secara integral turut membentuk kegiatan sosial, sehingga teori strukturasi mengkorporasikan ruang waktu dalam jantung teori sosial. Jadi yang dimaksud dengan ruang (space) disini bukan sekedar fisik melainkan ruang sosial (Social space), yaitu interaksi manusia dengan ruang fisik, seperti pedesaan, dan perkotaan, tempat kerja dan tempat tinggal, pasar tradisional dan pasar swalayan besar, kampus dan kantor birorasi. Dan lapangan yang mapu menampung massa yang besar dan gedung pertemuan berkapasitas terbatas. Sementara yang dimaksud waktu (Time) disini bukan sekedar sejarah kronologis melainkan pengalaman belajar dari peristiwa masa lalu, seperti pemilihan pemula dan pemilih kerap, trauma politik, dan pendidikan politik pada masa lalu.

Berbicara tentang ruang, Giddens juga mengartikan ruang lebih sebagai lokal dari pada sebagian tempat. dalam konteks tempat Giddens menawarkan konsep regionalisasi yang menunjuk pada pola lokalisasi atau penzonaan aktivitas sosial sehari - hari dalam ruang waktu. Berbagai ruang tersebut tidaklah sama penggunaan, menyangkut waktu penggunaannya , siapa menggunakan, untuk aktivitas apa digunakan, maupun tata cara digunakan. Suatu Ilustrasi yang mengisyaratkan adanya regionalisasi atau adanya penzonaan aktivitas sosial sehari-hari dalam ruang dan waktu. Suatu regionalisasi bisa tergolong kawanan pusat (sentral region), kawasan pinggirang ( peripheral region) tergantung pada beberapa utama suatu aktivitas beserta seberapa besar curahan waktu pada lokal atau zona bersangkutan; bisa pula tergolong "kawasan depan (front region) ataukah kawasan belakang (back region), bergantung pada sofat artikulasi zona tersebut, apakah lebih dalam ataukan keluar dan bisa pula tergolong kawasan terbuka (disclosure) atau kawasan tertutup (enclosure), tergantung pada kadar keterbukaan/ketutupan zona tersebut bagi pihak luar (Wirawan, 2011:302).

Seperti yang di kemukakan, waktu dan ruang merupakan variabel penting dalam teori strukturasi Giddens. Waktu dan ruang tergantung pada apakah orang lain hadir untuk sementara waktu atau dalam hubungan yang renggang. Kondisi promodial adalah interaksi tatap muka, dimana orang lain hadir pada waktu dan tempat yang sama, tetapi sistem sosial berkembang atau meluas menurut waktu dan ruang sehingga orang lain tidak perlu lagi hadir pada waktu yang sama dan di ruang yang sama ( Ritzer dan Goodman, 2004:512)

\section{METODE PENELITIAN}

Metode dalam penelitian sejarah adalah seperangkat aturan dan prinsip sistematis untuk mengumpulkan sumber-sumber sejarah. Secara sistematis dan menilainya secara kritis serta mengajukan sintesis secara tertulis.

Berdasarkan uraian tersebut dapat disimpulkan bahwa metode sejarah merupakan cara atau teknik dalam merekonstruksi peristiwa masa lampau, melalui empat tahapan kerja, yaitu heuristik (pengumpulan sumber), kritik sumber (eksterrnal/bahan dan internal/isi), interpretasi (penafsiran), dan historiografi (penulisan kisah sejarah).

Penelitian ini menggunakan penelitian sejarah yang bersifat deskriptif analisis yang memakai sumber - sumber tertulis atau bahan dokumen dan wawancara dengan pelaku atau saksi sejarah peristiwa Galung Lombok. Penelitian ini berusaha memberikan gambaran yang konfrehensif tentang latar belakang terjadinya peristiwa Galung Lombok tahun 1947, kronologis dan dampak peristiwa tersebut. Maka diperlukan data yang valid baik data sekunder maupn data perimer dalam menjelaskan peristiwanya.

Jenis penelitian ini adalah penelitian kualitatif dengan pendekatan sosial dan historis yang menjelaskan proses terjadinya peristiwa Galung Lombok . Dimana penelitian kualitatif memandang realitas secara subjektif. Dalam penelitian ini penulis berusaha menangkap pemahaman subyek penelitian (native understanding) tentang nilai, norma dan makna dibalik gejala yang diamati.

Penelitian tentang peristiwa Galung Lombok tahun 1947 di Polewali Mandar. Pemilihan daerah penelitian ini dilakukan dengan purposive yaitu pemilihan sevara 
sengaja, penentuan lokasi penelitian di kabupaten polewali mandar dengan pertimbangan didaerah tersebut merupakan wilayah pembantaian besar besaran yang dilakukan oleh tentara tentara Westerling. Selain itu daerah Galung Lombok juga merupakan daerah basis pergerakan kelaskaran.

\section{Tehnik Pengumpulan Data}

\section{Heuristik}

Heuristik merupakan kegiatan mengumpulkan sumber informasi atau keterangan lengkap dan menyeluruh menyangkut obyek studi ini. Sumber- sumber tersebut berupa naskah atau dokumen tertulis, dalam hal ini penulis mengumpulkan berbagai informasi mengenai perjuangan peristiwa sejarah Galung Lombok 1946-1947.

\section{a. Penelitian Pustaka}

Sesuai dengan judul penelitian, penulis mencari dan mengumpulkan sumber dengan metode kajian pustaka, yang dimana penulis mengkaji beberapa sumber yang terkait dengan penelitian ini yakni buku tentang sejarah perjuangan.

Buku tentang sejarah perjuangan yang bisa didapatkan dengan mengunjungi Perpustakaan UNM, Balai Kajian Sejarah dan Nilai Tradisional Makassar, Perpustakaan Nasional Propinsi Sulawesi Selatan, Perpustakaan Multimedia, Balai Arsip, dengan menggunakan buku-buku pribadi, dan juga lembaga-lembaga yang terkait dengan masalah sejarah lokal, misalnya Museum Mandar, Perpustakaan daerah Polman, Perpustakaan daerah Majene, Perpustakaan Provinsi Sulbar serta tempat lain yang berhubungan dengan penelitian ini.

\section{b. Penelitian Lapangan}

Untuk penelitian atau pengumpulan data di lapangan nantinya akan digunakan teknik interview(wawancara). Wawancara ditujukan pada tokoh-tokoh masyarakat yang terlibat maupun mengetahui peristiwa Galung Lombok 1946 - 1947.

Untuk itu, peneliti akan diarahkan dengan pedoman wawancara, dalam pelaksanaan metode wawancara ini, penulis menggunakan kegiatan wawancara terstruktur. Wawancara terstruktur dilakukan oleh seorang peneliti dimana terlebih dahulu ia menyusun daftar pertanyaan sebagai pedoman wawancara (Ahmadin, 2013).
Selain itu, peneliti juga melakukan observasi (pengamatan) yaitu mengamati kondisi lokasi penelitian daerah Galung Lombok. Karena peneliti tidak bisa mengamati peristiwa yangterjadi di masa lalu maka pengamatan dilakukan terhadap objek yang ada, termasuk perubahan- perubahannya, dan Peneliti akan melakukan pendokumentasian dari hasil observasi lapangan.

\section{Tehnik Analisis Data}

\section{Kritik Sumber}

Tahap kedua adalah kritik sumber yang terdiri dari dua aspek yaitu pengujian otentisitas (keaslian sumber) dan kredibilitas (tingkat kebenaran informasi). Adapun pengujian atas asli dan tidaknya sumber berarti yang diuji adalah aspek eksternal (fisik) sumber sejarah.

Penentuan keaslian suatu sumber berkaitan dengan bahan yang digunakan dari sumber tersebut, atau biasa disebut kritik eksternal. Sedangkan, penyeleksian informasi yang terkandung dalamsumber sejarah, dapat dipercaya atau tidak, dikenal dengan kritik internal. Setiap sumber sejarah diperlakukan sama, yakni diseleksi bagi segi eksternal maupun internalnya.

Tahap penyeleksiannya harus sistematis, yakni diawali dengan kritik eksternal dan kemudian kritik internal. Jika tahap pertama suatu sumber sejarah tidak memenuhi syarat sebuah sumber sejarah (dari segi otentitasnya), tidak perlu dilanjutkan verivikasi tahap berikutnya (Madjid, M. Saleh, dkk. 2008:53-54)

\section{Interpretasi}

Dalam penulisan sejarah, digunakan secara bersamaan tiga bentuk teknis dasar tulismenulis yaitu deskripsi, narasi dan analisis. Ketika sejarawan menulis sebenarnya merupakan keinginannya untuk menjelaskan (eksplanasi) sejarah, ada dua dorongan utama yang menggerakkannya yakni mencipta ulang (re-create) dan menafsirkan (interpret) (Helius Sjamsuddin,2007: 157-158)

Interpretasi merupakan penafsiran terhadap kasus yang diteliti setelah selesai pada tahap kritik.Pada tahap ini penulis mencoba menghubungkan fakta- fakta yang telah diperoleh berdasarkan urutan kronologis peristiwa. Pada tahap ini dituntut kecermatan dan sikap objektif sejarawan terutama dalam hala interpretasi subjektive terhadap fakta sejarah(Saleh Madjid,2008: 56) 


\section{Teknik Penulisan}

\section{Historigrafi}

Historiografi merupakan penulisan setelah dari ketiga proses sebelumnya telah selesai, dalam hal ini adalah penyaji dari apa yang telah kita tulis. Hasil penulisan tersebut merupakan hasil dari penemuan sumber-sumber yang diseleksi melalui kritik, kemudian diinterpretasi lalu disintesa untuk kemudian disajikan secara deskriptif. Tahapan historiografi sebagai tahapan akhir menunjukkan karasteristik penulisan sejarah itu sendiri.

Historiografi merupakan puncak dari segala-galanya dalam metode penelitian sejarah. Sejarawan pada fase ini mencoba menangkap dan memahami histoire ralite atau sejarah sebagaimana terjadinya. Dalam konteks itu, penulisan sejarah tidak hanya sebatas menjawab pertanyaan elementer atau deskriptif mengenai: apa, siapa, kapan, dan bagaimana suatu peristiwa terjadi.

\section{HASIL DAN PEMBAHASAN}

\section{A. Gambaran umum Lokasi Penelitian}

\section{Keadaan Geografis dan Keadaan Demografis \\ a. Keadaan Geografis}

Kampung Galung (Lombok) adalah nama sebuah kampung kecil yang secara administratif pemerintahan termasuk dalam wilayah desa Galung Lombok, Kecamatan Tinambung Kabupaten Polewali Mandar. Berjarak kurang $300 \mathrm{~km}$ sebelah utara kota makassar, $3 \mathrm{~km}$ dari kota Tinambung, ibukota kecamatan tinambung dan pusat pemerintahan ex kerajaan / swapraja Balanipa dan sekitar 7 $\mathrm{km}$ dari kota Majene, ibu kota Kabupaten Majene dan ibukota ex afdelin Mandar (Amir,2010:17).

\section{b. Keadaan Demografi}

1. Orang Mandar

Secara demografi, kampung Galung Lombok dihuni penduduk yang homogen, bahkan masih merupakan satu rumpun keluarga. Seperti halnya dengan orang mandar pada umumnya, tipologi atau karakter masyarakatnya cenderung keras, kuat dan tak mudah menyerah. Secara filosofis mereka menjadikan siri' (harga diri) sebagai perisai atau benteng dalam menjalani interaksi kehidupan sosial mereka, terutama terhadap komunitas diluar masyarakat mandar. "Menjaga jati diri/ identitas sebagai orang Mandar".satu kata dan masih sering dipergunakan sampai pada saat ini di bagian hulu sungai Mandar sampai ke Pitu Ulunna Salu, yaitu Mandar sama dengan Manda'yangartinya kuat (Syah,1997:1).

2. Bahasa Mandar

Bahasa daerah yang dipakai sebagai bahasa ibu oleh suku bangsa Mandar di bekas Afdeling Mandar (Kab. Polman, Kab. Majene, Kab. Mamuju, Kab. Mamuju Utara, Kab. Mamuju Tengah dan Kab. Mamasa ). Kelompok masyarakat Mandar di desa Ujung Lero, Kab.Pinrang dan Kab. Pangkep, khususnya yang ada di pulau- pulau. Mengelompokkan bahasa Mandar menjadi 4 subkelompok yaitu (1). Subkelompok Mandar, (2). Subkelompok Pitu Ulunna Salu, (3). Subkelompok PadangMamuju dan (4). Subkelompok BottengTappalang. Sub kelompok Mandar terdiri atasa dialek-dialek Balanipa, Majene, Pamboang, Sendana dan Awoq Sumakuyu. Sub kelompok Pitu Ulunna Salu terdiri atas dialek-dialek Mambi- Mehalaan, Aralle-Tabulahan, dan UluMandaq. Subkelompok Padang-Mamuju terdiriatas dialek-dialek Mamuju, Padang, Sinyonyoi, dan Sondoang. Subkelompok Botteng-Tappalang terdiri atas dialek-dialek Botteng dan Tappalang. Dialek-dialek keempat subkelompok mempunyai variasinya sendirisendiri. Sejak dahulu sampai sekarang, berkedudukan sebagai bahasa pertama oleh para penuturnya.

\section{Tradisi Lisan atau Cerita}

Asal usul suatu suatu masyarakat senantiasa diliputi tentang manusia pertama. Mitologi ini dimaksudkan sebagai jalan keluar dari kebentuan sejarah asal-usul suatu masyarakat. Hadirnya sosok manusia pertama atau generasi awal menjadi sangat penting untuk melihat keberlanjutan sejarah sosial manusia itu sendiri. Konsepsi tentang manusia pertama senantiasa diliputi dengan mitos dan penafsiran yang muncul begitu saja. Beberapa sejarawan Mandar menghadirkan sosok manusia pertama mengikuti logika manusia pertama di manusia Bugis yaitu Tomanurung. Tomanurung adalah manusia yang dikonsepsikan sebagai manusia langit yang turun ke bumi melalui cara yang unik dan ajaib. Di Mandar setidaknya ada empat cerita tentang Tomanurung yang tertulis dalam 
beberapa Lontaraq Mandar. Tomanurung tersebut adalah Tokombong di Bura (orang yang datang dari Busa Air), Tobisse di Lattang (orang yang datang melalui Belahan Bambu), Tonisesseq di Tingalor (orang yang keluar dari perut Ikan Tingalor) dan Tomonete di Tarauwe (orang yang datang Meniti Pelangi) (Idham,2015:1-2).

\section{Perekonomian Penduduk}

\section{1). Darat}

Wilayah dataran tinggi di Mandar yang bisa dibilang lumayan luas dipergunakan masyarakat dalam mengembangkan ekonominya. Misalnya dalam bidang Pertanian, Peternakan dan Perdagangan. Dalam bidang pertanian di Mandar penggarap disebut dengan Passawal, yaitu apabila seseorang menggarap tanah atau kebun milik orang lain, maka hubungan antara pemilik sawah dan penggarap disebut sistem bagi hasil. Tanah pertanian umumnya dimanfaatkan oleh kaum tani di desadesa pertanian sebagai tanah ladang dan sawah milik keluarga. Tanah ladang yang digarap oleh petani disebut Panguma dan tanah persawahan disebut Pattigas.

Pekerjaan pertanian dikerjakan oleh laki-laki dan dibantu oleh perempuan. Para petani di Mandar biasanya menanam tanaman, seperti kelapa, mangga, jagung, jeruk,pisang, lansat, rambutan, ubi kayu, ubi jalar dan coklat. Serta banyak pula yang mengerjakan sawah yang ditarik oleh kerbau dan sapi. Selain bertani di Mandar para petani di Mandar juga banyak yang memelihara ternak. Seperti kambing dan sapi, ternak-ternak di Mandar kebanyakan di kirim ke Kalimantan. Dalam bidang perdagangan di Mandar bahkan pernah berdiri Syarikat Dagang Mandar yang berdiri di Padang, Sumatera Barat pada tahun 1923 dipelopori oleh kaum ada'. Para pedagang memasarkan barang dagangnya dalam daerah sendiri, antar daerah dan bahkan antar pulau (Idham, 2015:3).

2). Laut

Kondisi wilayah indonesia yang separuhnya laut ditaburi pulaupulaumengindikasikan pentingnya pelayaran dan perniagaan. Peran pelaut, dalam konteks ini, sangat penting menghubungkan kebutuhan penduduk di pulau-pulau yangterpisah. Aktivitas tersebut melahirkan suku-suku bahari seperti Bugis, Makassar, Mandar, Buton dan Madura. Semuanya berasal dari daratan Sulawesi kecuali Madura (Hamid,2011:1).
Mandar terkenal dengan budaya baharinya dan pelayarannya, buktinya di beberapa daerah di Indonesia terdapat kampung Mandar contohnya di Pinrang terdapat perkampungan Mandar yaitu Ujung Lero, perkampungan Mandar di Banyuwangi, Jawa Timur. Gresik terdapat kampung Mandaran dan masih banyak lagi di kalimantan dan pulaupulau lainnya di indonesia. Mandar juga terkenal dengan bermacam-macam jenis perahu seperti, Lepa-Lepa, Baggodan Sandeq. Perahu-perahuini biasanya dipakai dalam menangkap berbagai jenis ikan seperti ikan cakalang, tuna, layang dan lain-lain (Ridwan,2005:27)

\section{Persekutuan Mandar}

Perjanjian Tammajara adalah perjanjian yang mendasari terbentuknya persekutuan kerajaan Pitu Babana Binanga (tujuh kerajaan di pesisir pantai) yang terdiri atas kerajaan Balanipa, Sendana, Pambauang, Banggae, Tappalang, Mamuju dan Binuang. Demikian pula di daerah pedalaman atau pegunungan terbentuk sejumlah kerajaan yaitu Rantebulahan, Tabulahan, Aralle, Mambi, Matanga, Tabang dan Bambang. Ketujuh kerajaan di daerah pegunungan itu, kemudian membentuk pula persekutuan yang dikenal dengan Pitu Ulunna Salu(tujuh kerajaan di hulu sungai). Selain persekutuan antara Pitu Babana Binangadan Pitu Ulunna Salumasih terdapat beberapa kerajaan lain dan salah satu diantara dari kerajaan tersebut adalah Kerajaan Passokorang yang terdapat di lembah aliran Sungai Maloso, Mapilli. Namun karena Raja Passokorangini zalim dan tidak satupun kerajaan yang dapat menandingininya, maka ia berbuat semaunya. Ketika Todilaling menjadi Maradia Balanipa, kerajaan ini kemudian berkembang menjadi besar dan dapat menandingi Kerajaan Passokorang. pada masa pemerintahan MaradiaBalanipa ke II Tomepayung Kerajaan Passokorang berhasil ditaklukan (Amir:2016:29-30).

\section{Pembahasan}

\section{Masa Sebelum Peristiwa Galung Lombok}

\section{A. Kedatangan Belanda}

Kedatangan Belanda dimulai pada tahun 1601 dan berusaha mengadakan hubungan dagang dengan Raja Gowa Sultan Alauddin, tetapi tidak mendapat perhatian. Kemudian pada tahun 1607 Belanda datang kembali dan kali ini 
mengirim Abraham Matysz ke Somba Opu untuk mengadakan hubungan dagang dan bahkan mengajak Gowa bersama-sama menaklukan Banda yang kaya rempah-rempah, akan tetapi ditolak oleh Sultan. Siasat Belanda itu disangka bahwa Sultan tidak menjadi paham, bahkan usaha Belanda untuk menguasai Gowa yang sangat strategis itu sudah diketahui oleh raja-raja Gowa sampai kepada Sultan Hasanuddin. Secara kronologis Belanda dapat dikalahkan pada tahun 1616. Pada tahun 1625 Gubernur Belanda Herman Van Der Speult kembali ke Somba Opu untuk berunding, tetapi maksudnya gagal. Kemudian pada tahun 1627 Gowa menyerang Belanda di Perairan Maluku dan perang berlangsung sampai tahun 1630 . Selanjutnya pada masa pemerintahan Sultan Hasanuddin Belanda melengkapi pasukannya untuk menghancurkan Kerajaan Gowa/Tallo, pada penyerangan tahun 1666 sampai 1667 (Syah, M. T. Azis. 1998:71).

Dalam perang ini, penguasa Makassar yang mendapat dukungan dari pasukan Mandar (laskar Mandar berjumlah sekitar 1.000 orang dibawah pimpinan Mara'dia Balanipa, I Daeng Mallari. Dalam pertempuran itu Mara'dia Balanipa tewas dalam pertempuran di Galesong pada 19 Agustus 1667. Perang ini dimenangkan oleh Belanda dengan sekutu utamanya Arung Palakka dari Kerajaan Bone, sehingga pihak pengguasa Makassar dan sekutu-sekutunya bersedia menandatangani naskah perjanjian perdamaian yang dikenal dengan sebutan Perjanjian Bungaya (18 November 1667) (Poelinggomang,, 2005:97).

Kemudian pada tahun 1669 Belanda bersama pasukan Kerajaan Bone menyerang Mandar. Dalam peperangan tersebut Mara'dia Bangae Tomatindo di Salambo gugur, tetapi peperangan dimenangkan oleh Mandar Pitu Ba 'bana Binagadan saat itulah I Daeng Rioso' dinobatkan menjadi raja di Kerajaan Balanipa yang ke IX.(Sinrang, 1994: 111)

Perang Mandar kedua terjadi di Balanipa dari tahun 1673-1674 (1 tahun), pada zaman pemerintahan Raja Balanipa Tomatindo di Langgana II. Dalam peperangan ini ikut Arung Palakka Malampe'e Gemme'na dan Karaeng Tompokbalangdari Gowa.(Ibid 112) Mengenai Karaeng Tompokbalang keikut sertaannya hanya secara pribadi, bukan atas nama Kerajaan Gowa. Pada peperangan ini Mandar dapat dikalahkan.

Perlawanan rakyat Mandar memuncak pada tahun 1905 di bawah pimpinan dua bersaudara Calo Ammana I Wewang dan Kaco Puang Ammana I Pattolawali. Calo Ammana I Wewang adalah raja di Kerajaan Allu dan merangkap sebagai Mara'dia Malolo (Panglima Perang) di Kerajaan Balanipa. Pada tahun 1907 Calo Ammana I Wewang tertangkap dan diserahkan kepada Belanda di Tinambung dan diasingkan ke Pulau Belitung, dan baru kembali ke Mandar pada tahun 1943 (Rahman, 2016 :910)

Perlawanan yang cukup besar di Mandar, juga terjadi tahun 1914 sampai tahun 1916, berupa perlawanan rakyat Pitu Ulluna Salu dibawah Pimpinan Demmatande, kepala kampung Peladan. Perlawanan rakyat Pitu Ulluna Salu itu, adalah sebagai reaksi terhadap tindakan sewenang-wenang pejabat Belanda dalam melaksanakan pemungutan pajak dan kerja rodi (Rahman, 2016 :9-10)

\section{c. Terbentuknya Organisasi}

Munculnya semangat perjuangan serta benih - benih Nasionalisme rakyat Mandar tidak terlepas dari munculnya berbagai organisasi pergerakan, baik yang berskala nasional maupun lokal. Salah satu organisasi pergerakan yang memiliki perang penting dalam membangun dasar nasionalisme rakyat Mandar adalah Serikat Islam (SI). Dalam Skala Nasional organisasi pergerakan ini resmi di akui oleh Pemerintah Kolonial Belanda sejak tahun 1912 pada masa pemerintahan Gubernur Jendral Idenburg. Organisasi pergerakan ini secara simultan melakukan perbaikan strategis organisasi, Sehingga pada tahun 1921, organisasi pergerakan ini berubah nama menjadi Partai Serikat Islam (PSI). Terkait dengan penyempurnaan ideologi kepartaian organisasi pergerakan ini kembali merumuskan dasar ideologi dan pergerakannya, sehingga nama Organisasi pergerakan ini juga berubah untuk ketiga kalinya dan menjadi Partai Serikat Islam (PSII)

Menurut Junaeda Dalam ahmad dan Marjana mengatakan bahwa Di wilayah Mandar Organisasi pergerakan SI telah mewarnai sejak awal dari proses pergerakan rakyat dalam upayanya membangun karakter kebangsaan. (SI) telah masuk dan berkembang di wilayah Mandar sejak tahun 1914. Salah satu wilayah yang saat itu secara resmi membangun pola komunikasi dengan organisasi pergerakan Nasional ini adalah dari Pamboang. Di Pamboang inilah SI didirikan dengan susunan keanggotaan sebagai berikut: Penasehat di duduki oleh Katang Puang 
Malai, Pa'bicara Bonde dan Puang Galung, Pa'bicara Adolang serta Pa'bicara Lalampanua. Ketua atau presiden partai diduduki oleh Muhammad Kanna Baso, Kadhi Pamboang. Wakil President Partai diduduki oleh H.Mahmud, Sekertaris dijabat oleh H Djuhaeni dan $\mathrm{H}$ Mahmud wakil Kadhi Pamboang. Beberapa komisaris diduduki oleh empat orang yakni: Darwis Puanna Mansur (Kepala Kampung Tinambung), H. Zaman (Pedagang), Buto Kanna Baejuri (Pedagang) dan Ledang (Pemuka Masyarakat) (Ahmad dan Marjana,2007:107-108).

Sebagai organisasi Progresif, SI menjalankan roda pergerakannya dengan membangun organisasi sayap kepanduang yang saat itu diberi nama SIAP (Serikat Islam Afdeling Padvinder) Organisasi kepanduan ini sangat produktif dalam menegembangkan berbagai kegiatan yang bersifat sosial. Oleh karena itu Organisasi pergerakan SI dan organisasi sayap SIAP ini senantiasa menggelar Rapat umum yang dilakukan di pasar Pamboang dengan jumlah peserta yang hadir mencapai ribuan.

Dimandar pada umumnya dan majene pada khususnya, persebaran dan pendirian organisasi pergerakan Muhammadiyah juga tidak berselang lama dengan pendirian organisasi pergerakan SI. Muhammadiyah berdiri di derah Mandar pada tahun 1914, beberapa kegiatan yang dilakukan oleh Muhammadiyah tentunya tidak jauh dari hal hal yang berkaitan dengan keagamaan dan pendidikan. Dibidang sosial keagamaan Muhammadiyah melakukan pengumpulan zakat untuk kemudian di salurkan kepada fakir miskin di Majene, begitupun dalam bidang pendidikan Muhammadiyah bekerjasama dengan SI mengorganisisr masyarakat dalam bidang pendidikan, dimana secara bersama-sama mereka membangun lembaga pendidikan secara bertahap dari madrasah Ibtidaiyah, Tsanawiyah hingga Madrasah Aliyah.Hal ini dapat dilihat adanya beberapa sekolah - sekolah yang bercorak Islam di daerah Mandar.

Organisasi Perjuangan Rakyat Mandar(PRAMA), secara resmi di bentuk untuk mengakomodir serta menggalang kekuatan rakyat Mandar baik dalam segi Perekonomian, Sosial, Budaya serta Politik maupun Keagamaan. Organisasi PRAMA juga dijadikan sebagai wadah pemersatu bagi seluruh rakyat mandar yang saat itu menetap di beberapa daerah lain di luar mandar. Sehingga hubungan komunikasi anatara sesama orang Mandar di beberapa daerah yang berbeda masih tetap terjalin dengan baik. Langkah maju yang dilakukan oleh organisasi ini adalah mengirim pelajar ke daerah di wilayah Sulawesi Selatan, Padang, Padang Panjang dan Bukit Tinggi (Junaeda, 2013:55).

\section{d. Kedatangan Jepang}

Sejak Indonesia resmi di bawah kekuasaan Jepang pada awal 1942 dan Tentara pendudukan Jepang masuk di Mandar pada akhir bulan Februari 1942, tetapi aparat pemerintahan sipilnya yang sangat minim baru muncul di Balanipa sekitar tahun 1943, maka rakyat di Sulawesipun menyambut dengan gembira begitupun di daerah Mandar, situasi di sulawesi awal pendudukan Jepang dapat dikatakan Vakum atau pasif tidak melakukan kegiatan apa-apa, terutama pada kerajaankerajaan yang sebelumnya mendapat tekanan dari pemerintah Hindia Belanda dalam bentuk politik pecah belah atau devide et impera. oleh sebab itu sehingga aparat pemerintahan sipilnya yang menyusul kemudian memanfaatkan kenyataan itu dengan mengukuhkan kekuasaan raja-raja (Para Mara'dia) di bawah struktur penguasa Militer Jepang (Kadir dkk, 107107:1984)

Kedatangan pemerintah militer Jepang di Mandar dan di alu telah merubah tatanan dan pranata tradisional masyarakat setempat yang selama ini telah berlaku dan dihormati oleh masyarakat Mandar. Kebijakan pemerintah militer Jepang yang sangat merugikan rakyat dan tentunya menguntungkan pihak Jepang dimana mereka telah merubah kehidupan sosial rakyat pedesaanterutama dalam bidang kebudayaan dan pertanian, seperti adanya paksaan-paksaan untuk menarik pajak dan hasil pertanian rakyat. Hal itulah yang mengundang terjadinya tindakan spontanitas baik iyu sifatnya protes maupun fisik. Tingkah laku dan perbuatan sewenang-wenang penguasa Jepang yang menyebabkan timbulnya penderitaan di kalangan masyarakat Mandar, selanjutnya menimbulkan pula sikap anti Jepang (Amir,2014:98)

\section{e. Proklamasi Kemerdekaan}

Ketika Jepang menyerah tanpa syarat kepada Sekutu pada tanggal 15 Agustus 1945 dan dua hari kemudian Republik Indonesia di Proklamasikan dan diketahui oleh para pemuda 
Mandar, di Balanipa. Berita Proklamasi diterima oleh Ibu Andi Depu dan R.A Daud pada hari minggu 19 Agustus 1945 melalui Taico, Kapten Angkatan Darat Jepang untuk daerah Afdeling Mandar. Dimajene berita Proklamasi di terima melalui siaran radio Australia dalam bahasa Inggris dan Belanda kemudian menyusul dalam bahasa Arab dari radio Kairo (Sewang, 1992:2).

Hal yang menarik perhatian adalah munculnya gerakan - gerakan spontanitas rakyat dalam menyambut Proklamasi tersebut. Sambutan antusiasme rakyat agaknya dilatarbelakangi oleh tekanan penderitaan mereka pada masa pendudukan Kolonial Belanda maupu pada fasisme Jepang. Proklamasi merupakan tonggak sejarah bagi mereka untuk melepaskan diri dari penderitaan. Sehingga pekikan Merdeka terdengar dimanamana dan menjadi salam pada setiap pertemuan. Pengibaran merah putih tampak dibeberapa tempat, seperti di Majene, Balanipa, Campalagiang, Polewali, Pamboang dan Mamuju (Kadir dkk,1984:220)

Untuk mengarahkan dan mengkoordinasi semangat spontanitas rakyat diatas, pada tanggal 21 Agustus 1945 didirikanlah Kebaktian Rahasia Islam Muda (KRIS-Muda). Organisasi ini merupakan tindak lanjut dari organisasi Islam Muda yang didirikan pada bulan April 1945 (Pada Masa Jepang). Sebagai Organisasi yang terbentuk pada masa revolusi, maka pembentukan KRIS Muda dimaksudkan untuk mempertahankan kemerdekaan yang baru saja di Proklamasikan. Kegiatan mereka ini mendapat dukungan dari Ibu Andi Depu yang pada waktu itu berkedudukan sebagai Mara'dia Balanipa. Pengaruh dan perjuangan yang di canangkan oleh KRIS Muda Mandar ini berakibat pihak NICA akhirnya menangkap dan menahan seluruh anggota pengurusnya akan tetapi mampu lolos dalam penahanan yang dilakukan NICA (Sewang,1992:3).

\section{Peristiwa Galung Lombok}

Menurut Hutagalung dalam Moor; kedatangan Vermeulen yang memimpin rombongan dari 20 pasukan Depot Khusus pada tanggal 15 November 1946 menuju Makassar merupakan perintah dari Westerling untuk segera mungkin mengumpulkan data data dan melacak keberadaan pimpinan perjuangan Republik serta para pendukung mereka, hal ini didasari oleh hasil putusan Letnan Jendral Spoor dan kepala stafnya Mayor Jendral Buurman van
Vreden serta seluruh pimpinan pemerintah Belanda di Sulawesi Selatan yang di adakan di Markas besar di Batavia pada tanggal 9 November $1946 . \quad$ (Westerling's Oorlog,Indonesie 1945-1950:96)

Setelah Westerling Tiba di Makassar pada tanggal 5 Desember 1946, ia menerima data - data dari Vermeulen dan untuk meredam perlawanan rakyat di berbagai daerah maka Westerling mengambil tindakan yang keras dan tegas serta membagi pasukan ke beberapa daerah dan untuk di Mandar pasukan Khusus Westerling di pimping oleh VermeulenSementara untuk Westerling sendiri lebih banyak menjalankan strateginya di daerah Makassar, Polongbangkeng (Jeneponto), Parepare dan Suppa (Pinrang).

Diawali dengan metode dan pola operasi Pasukan Westerling di Daerah Sulawesi selatan, pada umumnya relative sama dimana tujuan mereka adalah meredam perlawanan dari berbagai kelaskaran. Dengan metode spesifikasi pasukan westerling melancarkan Eksisnya dengan melakukan terror terhadap rakyat yang di kategorikan sebagai Ekstremis, Teroris anarkis, Bandhit, Penjahat, Perampok serta orang - orang yang memiliki senjata api secara tidak sah ataupun membantu dan menyembunyikan orang - orang Criminal (Kadir dkk)

Westerling menyadari bahwa kekuatan pejuang gerilya terletak pada dukungan seluruh rakyat terutama logistik. Itulah sebabnya strategi pertama dilakukan adalah blokade ekonomi rakyat dimana rakyat di desa-desa terpencil di dengan paksa dan digiring kelapangan terbuka dengan suatu ancaman barang siapa membangkan yang menjadi sasaran adalah raja atau kepala kampung dengan jalan tembak mati. Selain itu pasukan Westerling dengan sengaja melakukan pembakaran rumah -rumah penduduk, pembunuhan massal serta perampokan harta benda. (Asba Rasyid, 2010:4)

Aksi pembersihan setelah pengumuman SOB dari beberapa data yang di temukan mengatakan bahwa kedatangan Pasukan Khusus atau Pasukan Depot Spiciale Troopeent (DST) di Mandar tidak di dampingi lansung oleh Westerling, akan tetapi Westerling terlebih dahulu memberangkatkan wakilnya under Luitnant Vermeulen untuk mengumpulkan beberapa data yang diperlukan pada dinas Penerangan Militer (MilitaireInlichtingendienst), NEFIS Makassar. 
Tanggal 30 Januari 1947 under Luitnant Vermeulen yang memimpin Operasi didaerah Mandar sampai di Majene bersama 9 orang serdadu Belanda, sedang selebihnya serdadu KNIL yang direkrut dari berbagai suku seperti Jawa, Ambon, dan Minahasa. Kedatangan pasukan Westerling di bawah pimpinan Vermeulen di Tanah Mandar lansung mendantangi penjara KNIL mengindentifikasi sejumlah Ekstremis yang ditawan di penjara itu. "Ekstremis" adalah sebuah istilah yang digunakan oleh Belanda untuk menyebut para pejuang Kemerdekaan yang melawan pada pemerintah Kolonial Belanda (Thalib Bandrung).

Tragedi Galung Lombok merupakan Sakuens dari beberapa rangkaian peristiwa sebelumnya. Dalam analisis beberapa sejarawan dan pengamat Hak Asasi Manusia (HAM), menyebut tragedi Penyapuang di Galung Lombok termasuk salah satu "messacre" (Pembantaian manusia terkejam dalam sejarah pembunuhan manusia di muka bumi).

Dalam Tulisan Manai Sophian (Mantan Duta Besar RI di Rusia) mengatakan bahwa pada tanggal 1 Februari terjadi pembunuhan di Mandar, Di galung - galung dimana orang orang di halau kelapangan terbuka, karena panik mereka melarikan diri dan kesempatan seperti itu dipergunakan oleh pasukan Westerling untuk mengadakan latihan tembak benda bergerak dengan sasaran manusia hidup. Hal serupa yang juga ada dalam bukuRaymond Westerling sendiri didalam buku memoarnya "Westerling de Eenling" (Westerling Manunggal Tunggal) yang terbit pada tahun 1983 di Amsterdam, menulis : Kami datang ke suatu desa semua penduduk kami kumpulkan di lapangan, seorang demi seorang diperiksa surat suratnya kemudian salah seorang harus menunjuk seorang Ekstremis klu tak mau maka ia ditembak, disuruh seorang lagi di tembak lagi. Demikian seterusnya baik yang di tunjuk maupun yang mennjuk pada akhirnya di tembak semua.

Menggiring massa ke galung lombok adalah salah satu strategi pasukan - pasukan Westerling di bawah pimpinan Vermeulen dengan maksud untuk meredam perlawanan gerakan anti Belanda di wilayah Mandar, dimana mereka merancang Strategi dengan upaya membuat "shok therapy"di kalangan masyarakat Mandar yang diketahuinya selama ini cukup ulet dalam gerakan perjuangan mempertahannkan Kemerdekaan. Sebagai Implementasi pasukan Westerling dibantu para "kaki tangannya" bergerak keberbagai tempat mengumpulkan warga sipil sebayak mungkin.

Bermula ketika pasukan Westerling di bawah pimpinan Vermeulen mengepung daerah baruga, simullu, sigeri, lembang, tande dan daerah-daerah sekitarnya pada 1 februari 1947. Untuk menakut - nakuti rakyat, pasukan belanda tersebut membakar rumah - rumah rakyat dan barang siapa yang melawan atau melarikan diri dan membawa senjata tajam akan di tembak mati di tempat. setelah seluruh rakyat berkumpul, mereka kemudian digiring ke Galung Lombok. Ditempat ini kemudian perempuan dan anak-anak dipisahkan dari kaum laki-laki. Seluruh rakyat yang berada di sekitar Galung Lombok dikerahkan untuk datang menyaksikan pengadilan massal yang di lakukan oleh pasukan Westerling tersebut dengan tujuan untuk menakut - nakuti rakyat agar tidak membantu para pihak pejuang, Pengumpulan warga yang dimaksud untuk diperlihatkan jasad sejumlah tawanan yang akan di Eksekusi, dengan asumsi bahwa dengan melihat lansung peristiwa itu akan berdampak sebagai Shok Therapy bagi para pejuang dan kelompok militan di daerah Mandar yang selama ini cukup merepotkan pemerintahannya. Paling tidak akan menimbulkan efek jera dan rasa takut untuk terus bertindak agressif terhadap pemerintah kolonial Belanda.

Muhammad,2010:193)

\section{Dampak peristiwa Galung Lombok}

Peristiwa Galung Lombok yang dilakukan oleh pasukan-pasukan Westerling merupakan luka yang mendalam, yang tak akan pernah terhapus dari memori kesadaran sejarah orang Mandar untuk selama-lamanya. Selain Trauma yang mendalam dirasakan oleh keluarga korban pembantaian terjadi juga kerusakan kerusakan yang diakibatkan aksi militer Belanda di Daerah Mandar yang berdampak pada kehancuran rumah-rumah rakyat. Seperti yang di kemukakan oleh Prof. Dr. A. Rasyid Asba, Ma dalam sebuah tulisannya tentang "Korban 40 ribu jiwa pelanggaran HAM berat di awal Kemerdekaan",yang menyatakan bahwa kerusakan-kerusakan yang diakibatkan aksi militer Belanda di berbagai daerah adalah :

1. Harta benda rakyat musnah terbakar yang membuat penduduk kekurangan makanan.

2. Jalan -jalan dan Jembatan banyak rusak yang dihancurkan oleh Gerombolan 
3. Hewan ternak rakyat banyak yang hilang

4. Desa pusat produksi makanan terpaksa di tinggalkan menuju ketempat yang aman.

Secara umum Peristiwa pembantaian 1 februari 1947 menyimpan trauma mendalam bagi istri, anak dan keluarga korban itu sendiri dimana setelah kejadian berdarah itu beberapa warga kampung harus pergi bersembunyi ke hutan beberapa hari apa lagi hampir semua rumah rumah warga hangus dibakar oleh pasukan pasukan westerling.

Menurut Adam (90 Tahun) anak dari Jugarang korban pembantaian di galung lombok menuturkan bahwa; "saat itu beliau sudah duduk di kelas 2 SR, beliau ingat betul bagaimana keadaan kampung saat kembali dari galung lombok bersama ibu dan adiknya yang baru saja lahir tiga hari yang lalu, hari itu sudah mulai gelap kira-kira sekitar jam 6 sore beliau melihat rumah rumah dikampung saya hangus terbakar, ibu sangat takut dan memutuskan untuk tinggal di rumah-rumah kebun dan hanya makan ubi kayu untuk beberapa hari, setelah beberapa hari barulah warga bergotong royong membuat rumah seadanya untuk warga yang terbakar rumahnya, sejak bapaknya tidak ada beliau membantu ibunya dengan menjadi buruh baik di kebun maupun di pasar rakyat" (Wawancara, 17 Pebruari 2017).

\section{SIMPULAN DAN SARAN}

Peristiwa Galung Lombok merupakan peristiwa pembantaian etnis Mandar yang dilakukan oleh pasukan - pasukan Westerling di bawah Kepemimpinan Vermeulen, Peristiwa yang mengakibatkan korban terhadap para Pejuang dan Rakyat Sipil yang tak Berdosa. Peristiwa yang terjadi pada 1 februari 1947 ini dapat di lihat dari tiga fase, yang memakan ratusan korban dalam waktu sehari.

Secara umum rentetan peristiwa penyapuang di Galung Lombok dapat di lihat dalam tiga fase (Episode):

1. Fase pertama (Pelaksanaan eksekusi mati terhadap 32 orang pejuang Mandar yang ditahan di penjara KNIL Majene)

Sabtu subuh/ pagi tanggal 1 februari 1947, 32 orang tahanan (Pejuang) itu diantar dengan beberapa buah mobil Jeep ke kampung Galung ( Lombok). Mereka dibawa dalam keadaan diikat (diborgol) dengan tali/kabel serta di bagi dalam beberapa kelompok. Dikampung Galung mereka dikumpulkan di sebuah lapangan/hamparan sawah yang baru selesai melakukan panen, sehingga tanahnya berlumpur dan terlihat tumpukan-tumpukan jerami dimanamana. Ditempat inilah pasukan westerling melaksanakan Eksekusi mati terhadap M. Jusuf Luasa(Paqbicara banggae) dan kawankawannya.

2. Fase ke dua : Membunuh Orang - orang yang di curigai sebagai Ekstremis.

Pasukan Westerling setelah mengeksekusi 32 orang pejuang, di bantu beberapa orang "begundal" nya (mata - mata) tiba - tiba masuk kedalam kerumunan ribuan manusia, menelisik satu persatu orang - orang yang menurut petunjuk begundal - begundalnya adalah ekstremis/ rakyat militant, mereka lansung ditembak oleh pasukan Westerling. Senjata diarahkan kebagian jidat atau kepala mereka.

Pencarian para Ekstrimis itu terus saja berlansung, diiringi dengan bunyi tembakan sang jagal. Sampai pada suatu batas para pegundal-pegundal itu tak menemukan lagi sosok ekstrimis yang dapat di umpangkan ke pasukan Westerling, tiba-tiba keadaan berbalik, beberapa orang dari begundal-begundal itu kemudian ditembak mati oleh tuanyya sendiri. Allahu Akbar.

3. Fase ke Tiga : Tragedi Penyapuang ( Pembersihan ) itu sendiri.

Setelah melakukan eksekusi tahap ke dua, pasukan Westerling itu nampak puas dan bersuka ria. Mereka Istirahat duduk sambil menikmati minuman - minuman Anggur dan roti keju. Mereka seolah - olah sedang merayakan suatu kemenangan besar. Ditengah keceriaan itu tiba-tiba muncul beberapa orang kurir. Mereka menghadap pada Vermeulen, lalu menyodorkan secarik kertas/ surat kepada sang komandan.seketika itu wajah Vermeulen nampak tegang, berdiri lalu berteriak sekeraskerasnya Verdomenche!. Ternyata isi kertas itu adalah laporan bahwa dikampung Talolo Segeri telah terjadi pengadangan terhadap Rombongan patroli Belanda oleh sekelomopok Pejuang/ Pasukan Gapri 5.3.1 dalam kontak senjata itu, tiga orang serdadu Belanda tewas, antara lain Van Eeu, Dykso dan satu orang yang tak diketaui namanya, sedang dipihak Gapri juga 
tewas tiga orang : Yonggang, Suarno, dan Harun.

Berita tewasnya 3 orang serdadu Belanda tersebut membuat Vermeulen Gerang dan akhirnya sang komandan kemudian memerintahkan anak buahnya membombardir ribuan massa. Tembakan senapan otomatis membabi buta menerjang kedalaman kerumunan ribuan warga, yang meradang ketakutan. Ratusan orang tewas, tumbang diterjang peluru, lalu menggelepar kebumi bagai binatang sembelihan.

Untuk menyelematkan diri dari dari kepungan peluru maut Belanda, beberapa warga menggunakan berbagai cara darurat, seperti berpura-pura mati dengan membenamkan diri kedalam lumpur yang sudah menyatu dengan darah.

Peristiwa Galung Lombok adalah peristiwa Sejarah yang sangat penting untuk di ketahui generasi Bangsa Indonesia, olehnya itu beberapa saran yang bisa diberikan:

a. Pelestarian Makan dengan melakukan penataan kembali agar dapat menjadi Objek sejarah yang dapat dikunjungi oleh masyarakat pada umumnya.

b. Peristiwa Galung Lombok ini seyogyanya dimasukkan dalam Kurikulum Sekolahsekolah untuk di jadikan bahan pelajaran Muatan Sejarak Lokal.

c. Seyogyanya Keluarga korban mendapatkan Konvensasi yang layak terhadap korban/ keluarga korban akibat Trauma mendalam yang dirasakan dari dampak peristiwa tersebut.

\section{DAFTAR RUJUKA}

Badan Arsip dan Perpustakaan Daerah Perwakilan Provinsi Sulawesi Selatan : Inventaris Arsip Pribadi H. M. Riri Amin Daud (1945-1985). No 17, 20, 456

Koleksi Badan Arsip Dan Perpustakaan Provinsi Sulawesi Selatan : Arsip Negara Indonesia Timur (NIT). No. 139.

Abduh, Muhammad dkk. 1982 Sejarah Perlawanan Terhadap Imperialisme dan Kolonialisme di Sulawesi Selatan Departemen Pendidikan dan Kebudayaan Direktorat Sejarah dan Nilai Tradisional Proyek
Inventarisasi dan Dokumentasi Sejarah Nasional.

Abdurrahman, Dudung.1999 Metode Penelitian Sejarah, Jakarta,Logos Wacana Ilmu.

Ahmadin, 2013. Metode Penelitian Sosial. Makassar, Rayhan Intermedia.

A.H.Nasution, 1977. Sekitar Perang Kemerdekaan Indonesia. Bandung, Angkasa.

Amir, M., 2014. Perjuangan Hammad Saleh menentang Jepang dan Belanda di Mandar 1942-1947. Makassar, Arus Timur.

2010. Kelaskaran di Mandar Sulawesi Barat: Kajian Sejarah Perjuangan Mempertahankan Kemerdekaan. Makassar, Dian Istana.

Asdi, Ahmad. 2007. Tragedi berdarah Korban 40.000 Jiwa di Mandar. Majene: Yayasan Mahaputra Mandar.

2000. Mandar Dalam Kenangan tentang Arajang Balanipa ke 52. Majene, Yayasan Maha Putra Mandar.

-------, 2014 Perjuangan Hammad Saleh Menentang Jepang dan Belanda di Mandar 1942 1947,Cet,1.,Makassar:Arus Timur.

-------, 2016. Penataan Mandar Masa Kolonial Belanda 1905-1942 Cet.1. Makassar:Arus Timur.

-------, 2014. Gerakan Mara'dia Tokape di Mandar 1870-1873 Cet.1.,Makassar:De La Macca,2014

Banru M Thalib 2017. Tragedi Penyapuan Di Galung Lombok ( Dalam bingkai perjuangan Lembaga Advokasi korban 40.000 Jiwa di Galung Lombok) Makalah

Bosra, Mustari "Tuang Guru, Anrong Guru, dan Daeng Guru:Gerakan Islam di Sulawesi Selatan 1914-1942 Cet.1.Makassar:La Galigo Press

BPS. 2013. Majene Dalam Angka. BPS Kabupaten Majene. 
Bahtiar. 2014. TRIPS Dalam Perjuangan Memperahankan Proklamasi Kemerdekaan di Sulawesi Selatan (1945-1950). Makassar: De Lamacca

Cahyo, A.N., 2014. Tragedi Westerling. Jogjakarta, Cetakan pertama. ed. Palapa, Banguntapan.

Hamzah, Aminah. Dkk. Biografi Pahlawan Hajjah Andi Depu Maraddia Balanipa.1991. ujung Pandang: Departemen Pendidikan dan Kebudayaan.

Hamid, Abd Rahman\& Muhammad Saleh Madjid, 2011. Pengantar Ilmu Sejarah ,Cet.1.,Yogyakarta:Ombak

Hamid, Abd. Rahman 2016. Nasionalisme Dalam Teror di Mandar Tahun 1947 "Paramita

Idham dan Saprillah, 2015.Sejarah Perjuangan Pembentukan Provinsi Sulawesi Barat ,Cet.2.,Solo:Zada Haniva.

Junaeda, St, Dkk. 2013:Nasionalisme Masyarakat Mandar Sejarah Kelaskaran Gapri 5.3.1 di Mandar Tahun 1945-1949,Cet.1.,Makassar:De LaMacca.

Kadir, Harun Dkk, Sejarah Perjuangan Kemerdekaan Indonesia diSulawesi Selatan1945-1950, Kerjasama Badan PerencanaanPembangunan Daerah Tingkat I Provinsi Sulawesi Selatan danUniversitas Hasanuddin, 1984.

Mandra, Abdul Muis. 2002. Sejarah Perjuangan Kemerdekaan di Mandar, Pemerintah Daerah Kabupaten Majene. Majene: Pemerintah Daerah Kabupaten Majene. 